\title{
Archaeological Sites as a Component of the Modern Religious Worldview of the Southern Ural Population (Based on the Example of the Akhunovo Megalithic Complex)*
}

\section{Ainur I. Tuzbekov, Albert T. Akhatov}

The present research examines the problem of the formation of new sacred sites around one of the most well-known archaeological complexes of the Bronze Age in the Southern Urals. To do so, the author applied the results of field research done of his own at the Akhunovo cromlech and analysed scientific literature and internet resources. Proceeding from the received data, the author traced the process of formation of sacred insight of the monument, determined the main reasons and participants of the sacralisation process and established probable negative outcomes of this phenomenon.

KEYWORDS: archaeological site, sacralisation, holy place, Akhunovo megalithic complex

\section{INTRODUCTION}

At present, within the territory of the Southern Urals, citizens are showing a growing interest in different beliefs - both conventional and unconventional. As an integral part of the religious practices of almost any religious doctrine, special sacred sites and objects are visited by pilgrims aimed at spiritual search, the performance of religious rites, appeal to 'the Higher Forces' asking to solve problems of life, and so on. Such places are considered having special, even mystical characteristics, which is why most active pilgrims and "higher knowledge" holders arrange numerous tourist trips and excursions to these places.

In connection to this, the study of existing and forming sacred objects is becoming one of the most cutting-edge directions in the humanities and social sciences, which provides an opportunity to analyse the process of their formation and function from the perspective of scientific knowledge, to research the activities of different religious unions, frequently using sacred objects for their own profit, to study the ritual-cultic practice and worldview of the modern population, and similar.

The research conducted by archaeologists of the Institute of Ethnological Research named after Kuzeev R. G. of the Ufa Federal Research Centre of the Russian Academy of Sciences (hereinafter: IER) in recent years has resulted in findings that the archaeological monuments of the Southern Urals are one of the main elements that form sacred sites (Akhatov, Bakhshiev, Tuzbekov 2016: 33-42).

* The article was prepared as part of the state task № AAAA-A18-118041290046-0 IES UFRC RAN 
The main part of them is generally known within some areas and districts, and only a few are known not only in the whole republic of Bashkortostan but beyond it as well. One of the most well-known objects of archaeological heritage, treated as a sacred site, is a megalithic complex called Akhunovo, which is located within the territory of the Uchalinsky District of the Republic of Bashkortostan. According to the information on the website "Association of Travel Agents" it is included in the "top 10 places in Russia, where wishes come true" taking the fourth place after the menhirs of Khakassia, Lake Baykal, and the natural reserve Arkaim (Sorokin 2011).

Despite its widely-spread popularity as one of the most important sacred centres of Russia, Akhunovo cromlech has scarcely been researched. In terms of cultural anthropology, there is some fragmentary information in the article by Serikov (2018: 88-89). Preliminary notes about the sacralisation of the menhirs of Akhunovo were given in the work by Akhatov, Bakhshiev, and Tuzbekov (2016: 38).

The goal of the present work is to analyse the sacralisation process of the menhirs of Akhunovo and determine their similar and distinctive features with comparable objects known in the Southern Urals.

In order to study the formation of sacred sites within the territory of the abovementioned object of archaeological heritage, we used the developments laid in a relatively new direction of anthropological and culturological studies - hierotopy. The term is

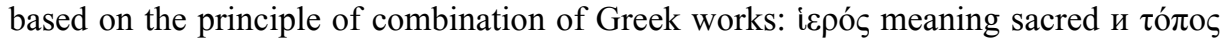
meaning place, space, idea. Hierotopy is a creation of sacred sites, seen as a special kind of spiritual and fictional art, as well as a special area of historical and cultural research that determines and analyses certain examples of this art (Lidov 2009: 11-37).

The study is based on the materials received through expeditions, organised in 2013 and 2019; the participants talked to local citizens, investigated the monument and took into consideration data summarised from mass media, internet resources published from 2003 to 2019, as well as information received from people who before/after attending the natural reserve of menhirs at Akhunovo came for an excursion to the Museum of Archaeology and Ethnography of IER to see the exhibition of the excavated materials.

\section{GENERAL INFORMATION ON THE OBJECT}

The Akhunovo megalithic complex is located on the outskirts of the village of Akhunovo of the Uchalinsky District of the Republic of Bashkortostan. The monument is $1.1 \mathrm{~km}$ to the south-west of a residential settlement on the right bank of the Kidish River; 70 metres to the west is a settlement (the late Bronze Age) called Akhunovo (Fig.1).

The object under research came to notice of the scientific community in 1996, when a local citizen named Aitov showed it to a group of anthropologists from Chelyabinsk University headed by Rybalko. In 2003, a complete study of the monument was conducted by an archaeological expedition led by Petrov, in which $860 \mathrm{~m}^{2}$ of its area was excavated (Petrov, Kirillov 2007: 19). In 2010, the object was researched by workers of the Scientific Production Center of the State Budgetary Institution of Culture, the Ministry of Culture of the Republic of Bashkortostan (Bakhshiev, Rafikova 2010). 
When menhirs of Akhunovo became known to the general public and started to attract many visitors, the central site and separate menhirs were fenced out. Nearby the place was equipped with facilities such as a car park, two garden pavilions, toilets, and several fire pits.

The megalithic complex itself consists of 13 granite menhirs of almost a regular quadrangular shape. Two of them - №1 and № 2 (the numeration was given by the archaeologist Petrov) - are located in the central part of the complex at the distance of 15 metres from each other towards the magnetic azimuth of north-south.

Eight menhirs (№ 3-10) are spread along the line of a circle with the centre in 5 metres to the west towards a magnetic declination from the central point of the line, which connects menhirs №1 and № 2. The circle is of almost a regular shape with diameter spreading from 23 to 26 metres depending on the direction of measurements (Fig. 1, 2).

Menhirs №11 and № 12 are located northwest-southeast $0.6 \mathrm{~m}$ from each other and in $80 \mathrm{~m}$ to the south-west from menhir № 10 of the central complex (Fig. 1, 3); menhir № 13 is $186 \mathrm{~m}$ northwest of menhir №10 (Fig. 1, 4). The height of menhir №1 is 1-1.65 m from the surface of the ground, while the general height is $2.05 \mathrm{~m}$. Menhir №2 is $1.4 \mathrm{~m}$ from the surface of the ground, and the general height is $1.6 \mathrm{~m}$. On average other menhirs are of $0.5 \mathrm{~m}$ from the surface of the ground with the general height of $0.75-0.8 \mathrm{~m}$ (Petrov, Kirillov 2007: 20).

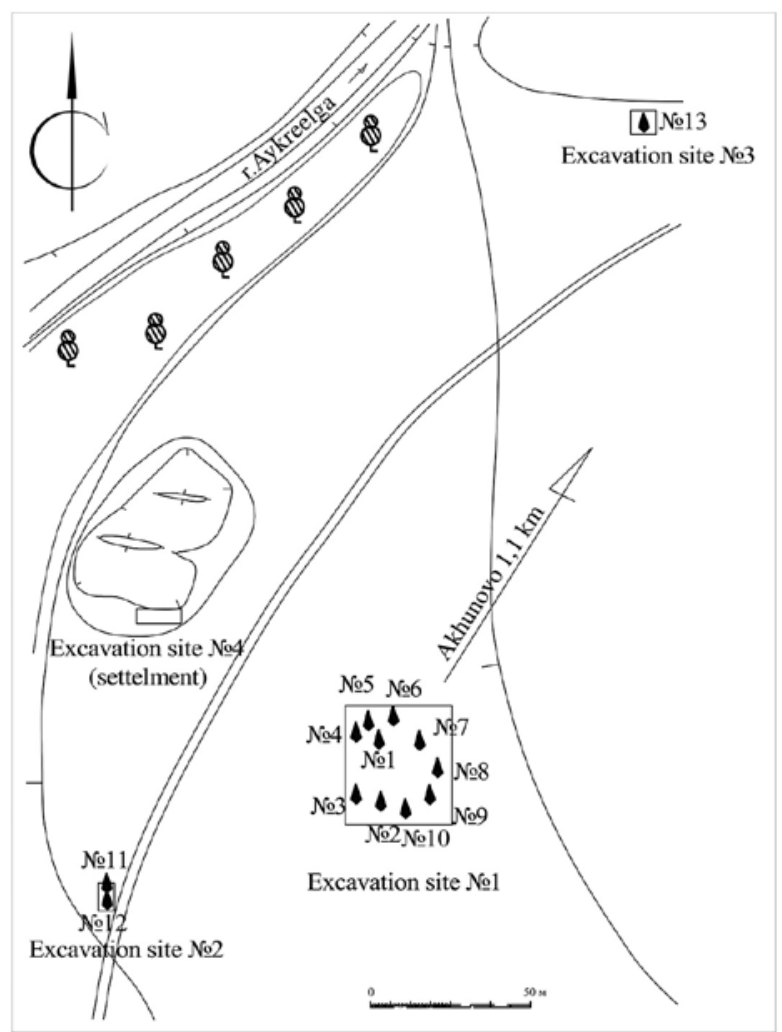

Fig. 1. Akhunovo megalithic complex. Plan. (Petrov, Kirillov 2007: 20, corrected Tuzbekov 2019). 


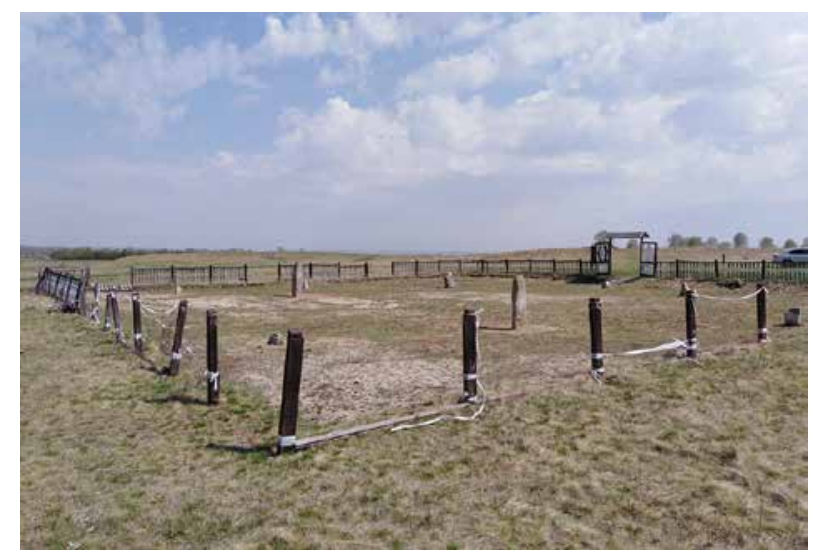

Fig. 2. Akhunovo megalithic complex. Excavation site №1 (photo by A. Tuzbekov, May 2019).

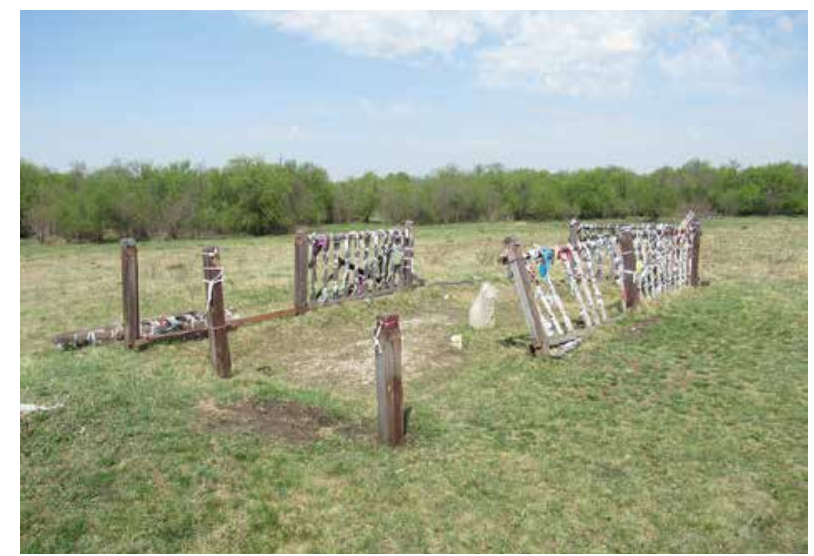

Fig. 3. Akhunovo megalithic complex. Excavation site №2 (photo by A. Tuzbekov, May 2019).

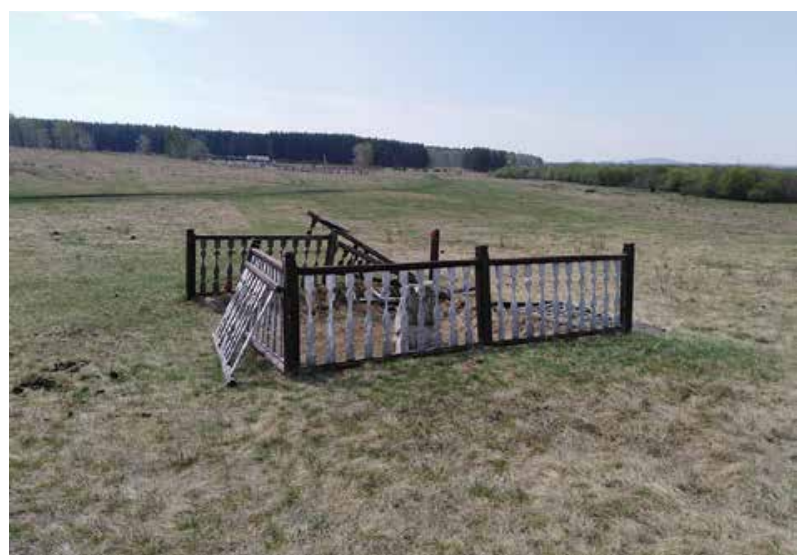

Fig. 4. Akhunovo megalithic complex. Excavation site №3 (photo by A. Tuzbekov, May 2019). 


\section{ARCHAEOLOGICAL AND ARCHAEO-ASTRONOMICAL ASPECTS}

In 2003, excavations around menhir № 1 revealed eight pillar holes of $0.2-0.25$ in diameter and depth that constituted a circle of $3.5 \mathrm{~m}$ in diameter. The location of the holes resembled the circle structure of eight menhirs № 3 to 10, each corresponding to a menhir in the great circle in its location.

According to Petrov, in ancient times the smaller circle was used to keep the calendar by tracing the shadow falling from menhir № 1 to the foot of the pillars towards menhirs № 3-10. Also, it could be used as a sun-dial (gnomon) (Fig. 5).

There were numerous fragments of ceramics found in the process of the excavations; the main part of them dated back to the Cherkaskulskaya and Mezhovskaya archaeological cultures of the Late Bronze Age in the $15^{\text {th }}$ to $12^{\text {th }}$ century BC. Furthermore, a few artefacts were found in the site which could date back from the Late Paleolithic Stone Age to the Bronze Age in a wide chronological range; also, there were bones of horses, cattle and small ruminants.

Another excavation site of $18 \mathrm{~m}^{2}$ was on a settlement where ceramic materials from Cherkaskulskaya and Mezhovskaya archaeological cultures, fractions of macrotools and two disks with holes in the centre made from soapstone and ceramics (Petrov, Kirillov 2007: 20-21) were found. All findings (221 items) are presently kept by IER.

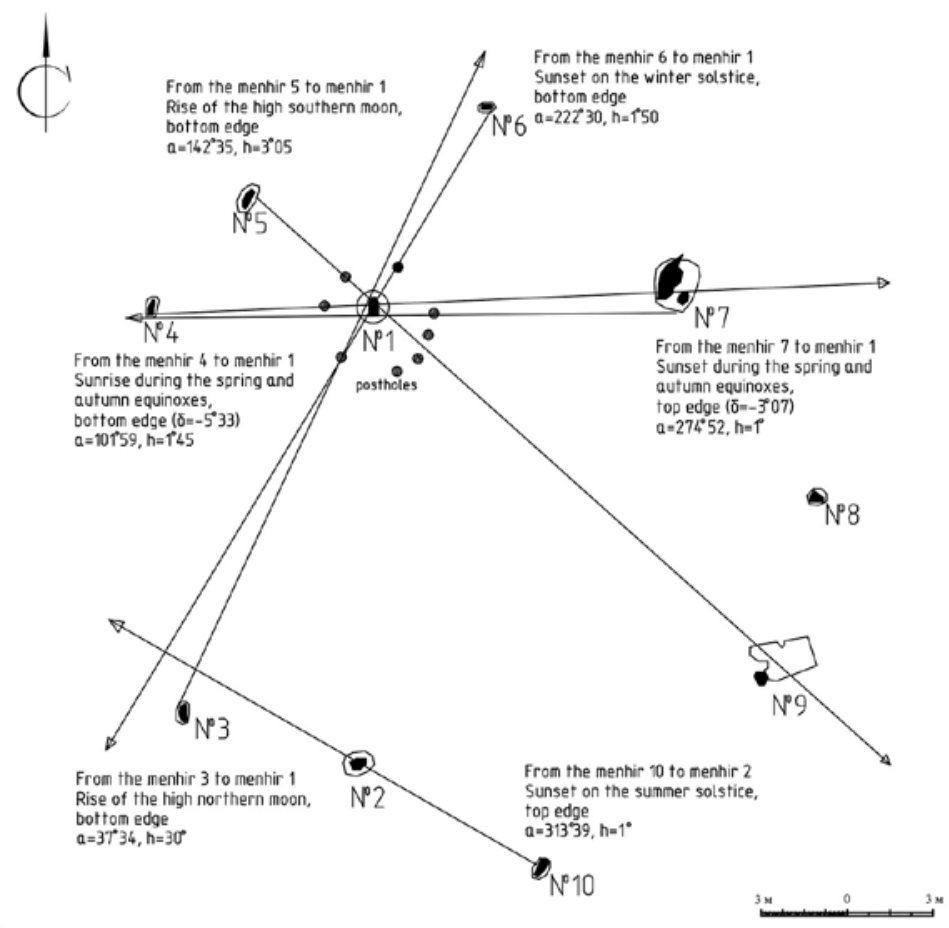

Fig. 5. Location of the central menhir № 1 tracing the shadow falling to the foot of other pillars. 
At that time, the researchers Kirillov and Nikitonova conducted archaeo-astronomical studies, the results of which enabled them to conclude that the megalithic complex is an ancient astronomical in-horizon observatory. The results of measurements and calculations determined the period in which the complex was constructed and used: from 1750 to $2000 \mathrm{BC}$. The most probable time is $1860 \mathrm{BC}$. Also, the calculations revealed that the key subject of the complex was menhir № 1. Separate menhirs of the circle system correspond to 'lunar' azimuths, denoting the point of moonrises in full distance position, closest to the point of the North and South (Petrov, Kirillov 2007: 21-22).

Other experiences of archaeo-astronomical research of cromlech enabled obtaining additional evidence about its layout, the sequence of construction, features of functioning, as well as the level of the astronomical knowledge of the ancient population of the Upper Ural Region (Potemkina 2011: 25-28).

In general, the received information allowed the researchers to view the Akhunovo megalithic complex not only as an ancient cult complex but as one of the biggest ancient observatories of Eurasia dedicated to observing astronomical events. In their opinion, the monument was used by the population of the Cherkaskulskaya and Mezhovskaya cultures in the Bronze Age in the latter half of 2000 BC. Based on the archaeological and archaeo-astronomical data, they suggested (which should be additionally verified) that it had been built earlier, in $3000 \mathrm{BC}$ in the Aeneolithic Period (Petrov, Kirillov 2007: 22-23).

\section{THE ETHNOGRAPHICAL ASPECT}

Local citizens from the village of Akhunovo with predominantly Tatar and Bashkir populations call the complex of Akhunovo "Alpamysh kabere" (the grave of Alpamysh). A giant named Alpamysh is a hero of a so-named folk heroical epic literature, found with some variations in the cultures of the Uzbeks, Kara-Kalpaks, Kazakhs, Bashkirs, Tatars, people of Gorno-Altaysk, and others. Despite its fictional and national distinctness, the Bashkir folk epic work "Alpamysh" ("Alpamysh and Barsynkhylu”) has the same storyline with similar works by other peoples (Yagafarov 2007: 11).

The story tells about a miraculous birth of Alpamysh and Barsinkhilu, the children of two neighbours Aylyar-khan and Akkubyak-khan, who were gifted with radiant beauty and heroic might. During premarital combat between the main characters, Alpamysh wins the fight and marries Barsynkhylu. Having lived for some time in a happy marriage, Alpamysh goes alone to fight enemies with the numerous army of Budyar-Khan and defeats him. The tired hero falls asleep in a heroic dream, during which the enemies bind him with steel chains and throw him into a pit, but he manages to get out of it with the help of the daughter of Budyar-Khan and his horse. Having returned home, he meets his son, who tells him about the competitions of the suitors, who claim Barsynkhylu's hand in marriage. Participating in the archery competition, Alpamysh defeats the opponents and restores peace and justice in the country (Zaripov 1987: 227-239).

According to local beliefs and legends, Alpamysh is the hero who had been buried under the menhir of Akhunovo. The local citizens say that in the past it was a forbidden 
place to visit as those who went there for nothing could bring misfortune upon themselves. Apart from that, the elderly used to come there to say their prayers. They called it "aulia kabere" ("the grave of the saint"). Some claimed menhirs to have healing properties that attracted ill people from the neighbourhood seeking the cure.

\section{THE CONSTRUCTION OF THE MODERN MYTH}

After the menhirs of Akhunovo became known to the general public in 1996, new myths and beliefs started to emerge, replacing the old legends. Their appearance was conditioned by an upsurge of esotericism and mysticism. Numerous healers, leaders of new religious movements declared the cromlech "a place of power". Travel agents began to organise various tours and trips to the complex of Akhunovo. Residents themselves made their contribution to it, talking about "wandering lights" on menhirs, "UFOs", and similar.

Later, the object received an additional impetus for sacralisation, after it was investigated by archaeologists in 2003. A special role to the sacralisation of cromlech was given by the fact that scientists put forward the opinion that "in terms of the structure and volume of reconstructed ancient astronomical observations" the menhirs of Akhunovo "are almost a direct analogue of the famous English megalithic structure of Stonehenge" (Petrov, Kirillov 2007: 19-23). This information was widely spread by the media, which caused a new wave of mystification. A large number of people started coming to the "Bashkir (Uchalinsky) Stonehenge".

Nowadays, one can distinguish several basic, closely interconnected ways people perceive the megalithic complex of Akhunovo, each of them having its followers and supporters.

The most popular and widespread is the esoteric view, according to which the megalithic complex of Akhunovo is a special sacred zone - a "place of power" that has the energy to help fulfil all wishes, cure diseases, including infertility.

The sacred meaning is attached to both the complex as a whole and individual stones. It is believed that the cromlech of Akhunovo has been a sanctuary or temple where ancient oracles and magicians performed their rituals. Also, there is a belief that a Lemurian crystal is hidden under it. Menhir №1 is seen as a symbol of the masculine principle, and menhir № 2 is the centre of female nature, both of which are endowed with special properties that together symbolise the duality of the world.

Closely related to the first is the opinion that links the menhirs of Akhunovo with aliens from outer space or parallel worlds interpreting the complex as a landing pad for flying saucers, an ancient alien observatory, a portal to other dimensions, and similar.

The third point of view perceives the cromlech of Akhunovo as a tourist attraction, that is often included in various tourist routes and as a part of weekend tours. In the early 2010s, the megalithic complex was included into an ecological and ethnographic tourist complex called "Europe-Asia", that embraced natural, historical and ethnographic sites (Municipalnye obrazovaniya 2012). 
The following point of view is a scientific one that is based on the archaeological research conducted at the monument. As already noted, during the excavation of the menhirs, archaeologists concluded that it was an ancient observatory for observing stars.

Jumbling together and spreading among people, all the scientific data, old and new myths, legends, and beliefs draw people's attention to the megalithic complex. On the internet, one can find information about tourist, sightseeing, exoteric tours organised in different years to visit the menhirs of Akhunovo lasting from one to several days: an on-site workshop "Menhirs of Akhunovo" (the Esoteric Center "Wisdom of the Urals") (Markina, 2017), an ecotour "Akhunovo-Iremel 2016" ("Center for Energy and Psychocorrection Matrix") (Po volnam pamyati ... 2016), a school tour "To the Menhirs of Akhunovo" (Tour operator Rinai) (Uchalinskiy Stonehenge), etc.

At the time of the examination in 2019, the megalithic complex of Akhunovo was on some decline, as evidenced by the fallen fences and decaying garden pavilions that had been built in previous years. However, even though the flow of visitors has decreased compared to previous years, local citizens say that a large number of people still come there.

It should be noted that some people of the population of Akhunovo have a negative attitude to the menhirs. So, for example, on the night of October 23-24, 2010, unknown people destroyed five out of ten menhirs and laid out an inverted cross from the remains with the intersection where menhir № 1 was located. To the east, in the conditional centre of the monument's platform, a pentagram was drawn at the ends of its five rays where circles were located. Traces of blood were recorded on some fragments of the destroyed menhirs, that is probably the evidence of sacrificial offerings (Bakhshiev, Rafikova 2010).

Obviously, this action was aimed primarily at the so-called desacralisation of the object. Subsequently, the remains of the menhirs were transferred to the museum of local history and residents installed stones similar in appearance at the place where the menhirs had stood.

Citizens from the Akhunovo village say that, as in previous years, on Muslim holidays people say collective prayers at the menhirs.

During the examination of the menhirs in 2019, at the top and at the foot of almost every one of them there were wheat grains, pieces of bread and coins of various denominations from 10 kopecks to 10 rubles. On the highest menhir № 1 in addition to grains and Russian coins, there were also hazelnut seeds and 20 euro cents (Fig. 6).

The fence that encloses menhirs № 11 and № 12 is tied with numerous multicolour strings of cloth; a few are also fixed on the fence of menhir № 13. It is believed that wishes will surely come true if you tie a ribbon to the fence (Fig. 3, 4).

Altogether, collective Muslim prayers, coins, grains, pieces of fabric brought as offerings are characteristic of almost all archaeological sites examined earlier that were sacralised in the Southern Urals (Akhatov, Bakhshiev, Tuzbekov 2016: 34).

At the same time, the available data suggest that the megalithic complex used to be a regional sacred centre; however, due to an increase in the flow of tourists, the archaeological site has become a "place of power" for representatives of various ethnic and religious groups and religious movements. 


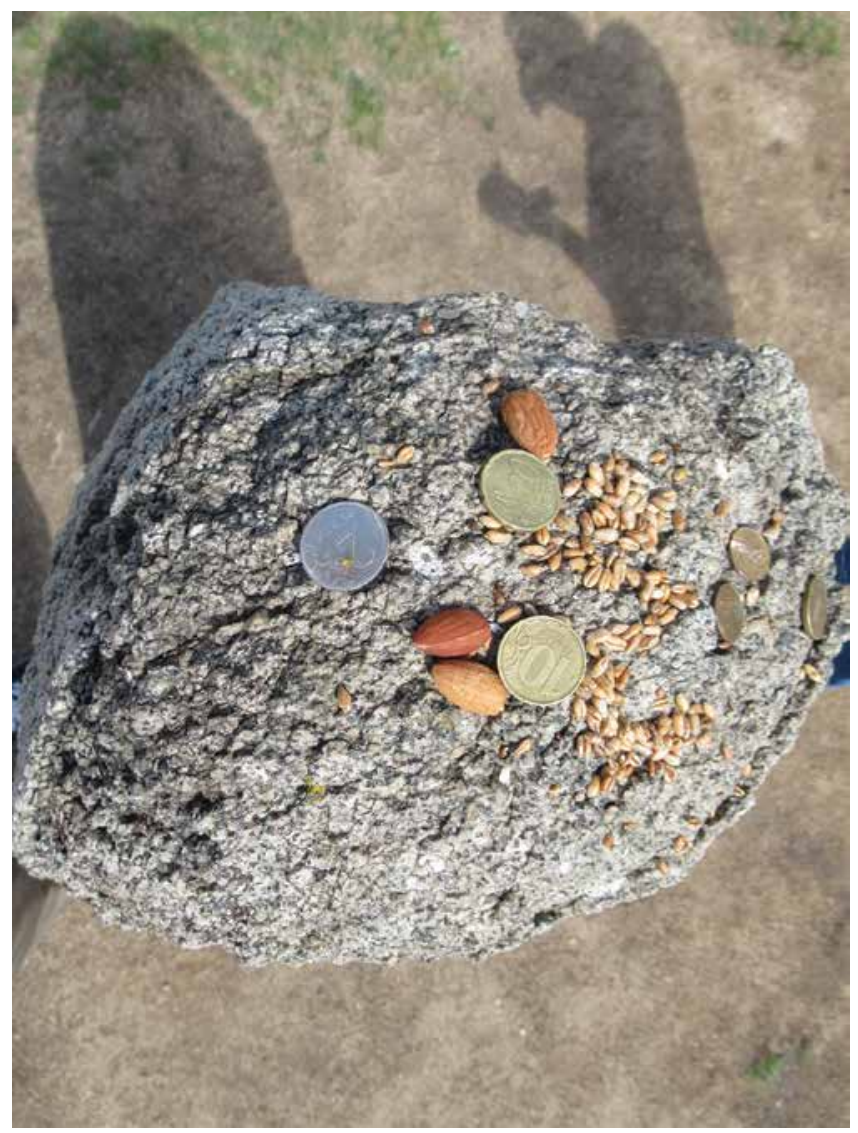

Fig. 6. Top of the Menhir № 1 (photo by A. Tuzbekov, May 2019).

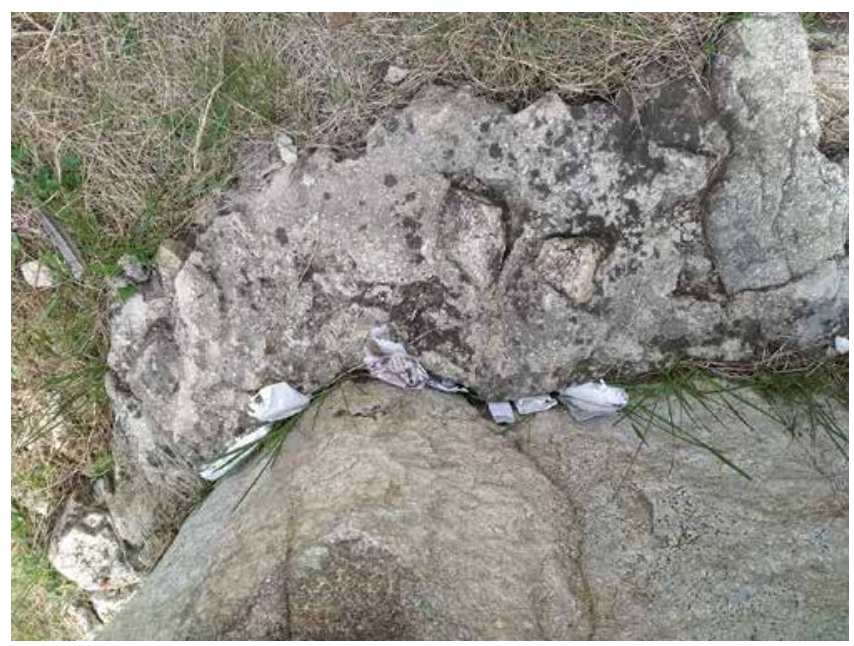

Fig. 7. Notes at the foot of the Menhir № 13 (photo by A. Tuzbekov, May 2019). 
Currently, various sacred practices are held there. On June 21, 2019, during the summer solstice, a group of people (both local citizens and visitors) gathered at the monument to perform rituals and rites.

In the course of the research, new elements of sacralisation of archaeological objects that had not been seen in Bashkortostan before were found; they were notes with wishes, left by pilgrims and tourists (Fig. 7). This tradition has been borrowed from the Arkaim natural reserve, located in Chelyabinskaya Oblast, which has long been well-known in Russia and abroad (Belolipetskaya 2007: 20-23; Shnirelman 2011: 133-167; Silina 2014: 211-223), which is where such tradition of leaving notes was first recorded (Silina 2014: 222).

In total, 11 notes of such type were discovered. They enable us to supplement our knowledge not only in the sphere of formation of hiertopies but in terms of understanding of the modern worldview of people and problems about which they are concerned.

The notes were left by the visitors in the cracks of menhirs №1 (one), №12 (two), № 13 (eight). Almost all of them are written in Russian, and only one is in the Bashkir language. They do not have any addressee expect for two addressing to God and Khozay ("God" in the Bashkir language).

The general content shows that the visitors are worried about both material and spiritual issues. However, despite all financial hardships among the majority of the Russian population, it is remarkable that wishes to have money, cars, and redecorate their home were mentioned only in three notes, whereas in six notes there are wishes to be healthy for addressors and their close ones; four notes mention a happy life with a husband: one note wishes for a clear sky and beautiful nature. Judging by the content of the notes, people visiting such objects are mostly concerned about the problems of health and family wellness, most notes were written by women, which corresponds to the results of the previously conducted research (Tuzbekov 2018: 44).

\section{CONCLUSIONS}

1. The research of the menhirs of Akhunovo exemplifies one of the models of sacralisation of an archaeological monument within the territory of the Southern Urals.

2. The absence of objective scientific findings on the archaeological monument published in media (mass media, internet resources) results in misleading information that circulates and is used to spread non-traditional religious doctrines and cults.

3. The majority of visitors of the sacred objects are middle-aged women who are concerned about their health and family wellness.

4. Uncontrolled and unregulated attendance of the archaeological monument, its involvement into the activities of representatives of new religious movements and further popularisation lead to additional anthropogenic pressure on the monuments, which is often seen as a significant transformation of both the monument itself and its surroundings and, in an extreme case, it might result in its destruction. 


\section{BIBLIOGRAPHY}

Ahatov, A. T.; Bahshiev, I. I. O.; Tuzbekov, A. I., 2016: Rol arheologicheskih obektov v formirovanii novyh sakralnyh prostranstv Yuzhnogo Urala. Uralskiy istoricheskiy vestnik 4 (53): 33-42.

Bahshiev, I. I. O.; Rafikova Y. V.; Bahshieva, I. R., 2010: Otchet ob itogah osmotra sostoyaniya pamyatnikov arheologii «Megaliticheskiy kompleks Ahunovo» $i$ «Poselenie Ahunovo» $v$ Uchalinskom rayone Respubliki Bashkortostan (kratkaya harakteristikai predlozheniya). Ufa: Arhiv GBUK NPC Ministerstva kultury Respubliki Bashkortostan.

Belolipeckaya, N. A., 2008: «Ezoteriki» Arkaima. Arheologiya v sovremennoy kulture Rossii. Chelyabinsk, 20-23.

Lidov, A., 2009: Ierotopiya. Prostranstvennye ikony i obrazy-paradigmy v vizantiyskoy kulture. M.: Feoriya.

Markina, I., 2017: Astromarafon. Praktikum 8 “Ahunovskie mengiry”. Internet: https://vk.com/ event144436552 (5.2.2020).

Municipalnye obrazovaniya Bashkortostana sozdayut turisticheskie brendy. Internet: https://ratanews.ru/news/news_13032012_18.stm (28.1.2020).

Petrov, F. N., 2008: Excavation report at the megalithic complex of Akhunovo and the settlement of Akhunovo. Chelyabinsk.

Petrov, F. N.; Kirillov, A. K., 2007: Issledovaniya megaliticheskogo kompleksa Ahunovo v 2003 g. Ufimskiy Arheologicheskiy vestnik 6-7: 19-23.

Potemkina, T. M., 2011: Megaliticheskie sooruzheniya urala struktura-sakralnogo prostranstva. Vestnik arheologii antropologii $i$ ehtnografii 2 / 15: 11-35.

Po volnam pamyati Giperborei. Dlya teh, chi Dushi i Razum ne spit. Internet: https://магиябиоэнергетики.рф/аркаим/ezotur-arkaim-iremel-2016.html (10.1.2020)

Serikov, Yu. B. 2018: Kultovye kamni i megaliticheskie sooruzheniya Urala. Ezhegodnik finno-ugorskih issledovaniy 12 /1: 80-97.

Shnirelman, V. A., 2011: Arkaim: arheologiya, ezotericheskiy turizm i nacionalnaya ideya. Antropologicheskiy forum 14: 133-167.

Silina, V. E., 2014: Kulytovaya deyatelynost netraditsionnykhreligioznykh dvizheniy na territorii zapovednika «Arkaim». Religioznoe mnogoobrazie Uralyskogo regiona. Materialy Vserossiyskoy nauchno-prakticheskoy konferentsii. Orenburg: IPK «Universitet», 211-223.

Sorokin, S., 2011: 10 mest v Rossii, gde ispolnyayutsya zhelaniya. Internet: http://kurortrussia.ru/ content/news/index.php?news=3838 (5.2.2020).

Tuzbekov, A. I., 2018: Gorodische u s. Kara-Yakupovo v Bashkirii - noviy obekt sakralizacii arheologicheskogo pamyatnika. Studia Mythologica Slavica 21: 93-49.

Uchalinskiy Stonehenge ili Ahunovskie mengiry. Internet: http://rinay.ru/tury-po-bashkirii/uchalinskij-stounhendzh-ili-ahunovskie-mengiry/ (28.1.2020).

Yagafarov, R. G., 2007: Bashkirskiy narodniy epos „Alpamysha i Barsynhylu“: genezis, specifika, poetika: avtoreferat dis. kandidata filologicheskih nauk. Kazan.

Zaripov, N. T., 1987: Bashkirskoe narodnoe tvorchestvo. Tom 1. Ufa: Bashkirskoe knizhnoe izdatelstvo, 227-239. 


\section{АРХЕОЛОГИЧЕСКИЙ ПАМЯТНИК КАК КОМПОНЕНТ СОВРЕМЕННОГО РЕЛИГИОЗНОГО МИРОВОЗЗРЕНИЯ НАСЕЛЕНИЯ ЮЖНОГО УРАЛА (НА ПРИМЕРЕ МЕГАЛИТИЧЕСКОГО КОМПЛЕКСА АХУНОВО) \\ АЙНУР И. ТУЗБЕКОВ, АльБЕРТ Т. АХАТОВ $\infty \infty$}

В работе рассмотрена проблема сакрализации археологических памятников на Южном Урале. На примере одного из наиболее известных в регионе археологических комплексов бронзового века, комплекса Ахуновских менгиров, авторы изучили модель формирования сакрального пространства. Для достижения этой цели учеными были использованы собственные результаты полевых исследований, проведенные на кромлехе Ахуново, результаты раскопок археологов, исследований проведенных фольклористами и этнографами, данные по памятнике содержащиеся в научной литературе, интернет-ресурсы. Используя полученные данные, исследователи смогли: 1) проследить процесс формирования сакральных представлений о памятнике, 2) установить основные причины и участников процесса сакрализации, 3) выявить, что отсутствие объективных научных данных о памятнике археологии в широком информационном пространстве приводит к появлению ложной информации о нем которая тиражируется и используется для распространения нетрадиционных религиозных учений и культов, 4) выяснить что бесконтрольное и не регламентированное посещение археологического памятника включение его в сферу интересов представителей новых религиозных движений и последующая их популяризация ведет к дополнительным антропогенным нагрузкам на памятники, что зачастую выражается в значительном преобразовании как самого памятника, так и его окружения, а в крайних случаях может привести к его полному разрушению.

\footnotetext{
Ainur I. Tuzbekov, Candidate of Historical Sciences, Research Fellow, R.G. Kuzeev Institute for Ethnological Studies - Subdivision of the Ufa Federal Research Centre of the Russian Academy of Sciences, K. Marx st., 6, Ufa, the Republic of Bashkortostan, Russia; tuzbek.80@mail.ru
}

Albert T. Akhatov, Candidate of Historical Sciences, Research Fellow, R.G. Kuzeev Institute for Ethnological Studies - Subdivision of the Ufa Federal Research Centre of the Russian Academy of Sciences, K. Marx st., 6, Ufa, the Republic of Bashkortostan, Russia; bertik@mail.ru 